\title{
Penganruh Penambahan Virgin Coconut Oil, Minyak Ilkan dan Minyak Zaitun dalam Pengencer Tris terhadap Kualitas Semen Cair Babi Landrace
}

\author{
Effect of Adding Virgin Coconut Oil, Fish Oil and Olive Oil in Tris Diluent Towards the \\ Quality of Landrace Boar Liquid Cement
}

A. B. Lawa, T. M. Hine, dan W. M. Nalley

Program Pacasarjana, Program Studi S2 Ilmu Peternakan, Universitas Nusa Cendana, Kupang. Corresponding Author: alvradobirelawa20@gmail.com

\begin{abstract}
This research aims to find the best combination of diluent and antioxidant withintris diluent in maintaining the quality of landrace boar liquid cement. The study used a complete randomized design with 4 treatments: $\mathrm{P}_{0}$ (egg yolk tris), $\mathrm{P}_{1}$ (egg yolk tris $\left.+\mathrm{VCO} 6 \%\right), \mathrm{P}_{2}$ (egg yolk tris + fish oil 6\%), and $\mathrm{P}_{3}$ (egg yolk tris + olive oil12\%) with 5 times ejaculates of 3 male Landrace boars aged between 3-4 years old. Accumulated fresh cement was evaluated macroscopically and microscopicallythen diluted with 2-hour holding time. After holding time, it was stored at a temperature of $18-20^{\circ} \mathrm{C}$ and evaluated every 8 hours on motility, viability and intact plasma membrane up to $40 \%$ of motility. Based on the results of this study, it is concluded that the best combination of diluent and antioxidants withintris diluent to maintain the quality of landrace boar cement up to 56th hour is $\mathrm{P}_{3}$ : egg yolk tris + olive oil $12 \%$ (T-KT + MZ) because it has the highest motility percentage of $(44.00 \pm 1.41 \%)$, viability $(54.78 \pm 1.50 \%)$ and Intact Plasma Membrane $(55.66 \pm 1.64 \%)$ compared to other diluent combinations.
\end{abstract}

Key words: boar cement, Tris, VCO, fish oil, olive oil

\begin{abstract}
ABSTRAK
Penelitian ini bertujuan untuk menemukan kombinasi pengencer dan antioksidan terbaik dalam pengencer tris dalam mempertahankan kualitas semen cair babi landrace. Penelitian ini menggunakan rancangan acak lengkap dengan 4 perlakuan: $\mathrm{P}_{0}$ (tris kuning telur), $\mathrm{P}_{1}$ (tris kuning telur $+\mathrm{VCO} 6 \%$ ), $\mathrm{P}_{2}$ (tris kuning telur + minyak ikan $6 \%$ ) dan $\mathrm{P}_{3}$ (tris kuning telur + minyak zaitun12\%) dengan 5 kali ejakulat dari 3 ekor ternak babi Landrace jantan berumur 3-4 tahun. Semen segar yang ditampung dievaluasi secara makrosopis dan mikroskopis kemuadian diencerkan dan holding time selam 2 jam. Setelah holding time kemudian disimpan pada suhu $18-20^{\circ} \mathrm{C}$ dan dievaluasi setiap 8 jam terhadap motilitas, viabilitas dan membran plasma utuh (MPU) hingga motilitas $40 \%$. Hasil penelitian ini disimulkan bahwa kombinasi pengencer dan antioksidan terbaik dalam pengencer tris untuk mempertahankan kualitas semen babi landrace hingga jam ke-56 adalah $\mathrm{P}_{3}$ : tris kuning telur + minyak zaitun $12 \%$ $(\mathrm{T}-\mathrm{KT}+\mathrm{MZ})$ karena memiliki presentasi motilitas $(44.00 \pm 1.41 \%)$, viabilitas $(54.78 \pm 1.50 \%)$ dan MPU $(55.66 \pm 1.64 \%)$ yang tertinggi dibandingkan dengan kombinasi pengencer lainyan.
\end{abstract}

Kata kunci: semen babi, tris, VCO, Minyak ikan, minyak zaitun

\section{PENDAHULUAN}

Reaksi peroksida lipid yang disebabkan oleh efek negatif radikal bebas sebagai hasil dari proses transport electron di mitakondria merupakan Salah satu penyebab kematian spermatozoa saat proses kriopreservasi. Radikal bebas mempunyai satu electron atau merupakan suatu atom atau molekul yang tidak berpasangan. Hal ini menimbulkan perubahan struktur spermatozoa terutama pada bagian akrosom, perubahan metabolisme yang cepat, pelepasan komponen intraseluler dan mengalami kehilangan motilitas spermatozoa (Jones dan Martin, 1973). Proses reaksi peroksida lipid apabila terjadi pada spermatozoa yang disimpan lama akan dapat merusak daya tahan spermatozoa selama proses kriopreservasi berlangsung.

Upaya untuk menghambat terbentuknya peroksida lipida dapat dilakukan dengan cara menambahkan antioksidan yaitu suatu zat yang dapat mengikat senyawa radikal bebas. Antioksidan adalah suatu senyawa yang pada konsentrasi rendah dihadapkan pada substrat yang dapat dioksidasi dan secara nyata menunda atau menghambat oksidasi dari substrat tersebut. Antioksidan berfungsi melindungi sistem biologi terhadap suatu efek yang memiliki potensi merusakan dari suatu proses reaksi yang menyebabkan oksidasi yang meluas (Lenzi et al., 2002). 
Antioksidan merupakan senyawa nukleofilik yang mampu mereduksi, memadamkan atau menekan reaksi radikal bebas.

Beberapa bahan alami yang mengandung antioksidan diantaranya adalah virgin coconut oil (VCO), minyak zaitun dan minyak ikan salmon. virgin coconut oil merupakan produk olahan asli Indonesia, dengan kandungan antioksidan yang sangat tinggi yaitu $0,5 \mathrm{mg} / 100 \mathrm{~g}$ minyak kelapa murni (Hernanto et al., 2008). Minyak ikan salmon mengandung $1970 \mathrm{mg}$ saturated fatty acid, 35,5\%, eicosa pantaenoic acid (PUFA) dan $120 \mathrm{mg}$ decosa hexaenoic acid sehinggamampu melindungi spermatozoa saat proses kriopreservasi. Minyak zaitun mengandung polifenol yang terdiri dari oleuropein, tyrosol, dan hydroxytyrosol. Oleuropein dan tyrosol dapat berperan sebagai antioksidan, sedangkan hydroxytyrosol berperan dalam melindungi membran sel.

Untuk melindungi spermatozoa terhadap daya merusak radikal bebas selama proses preservasi maka telah dilakukan penelitian tentang “ Pengaruh penambahan virgin coconut oil, minyak ikan salmon dan minyak zaitun dalam pengencer tris kuning telur terhadap kualitas semen cair babi Landrace". Penelitian ini bertujuan untuk menemukan kombinasi pengencer dan antioksidan terbaik dalam pengencer tris dalam mempertahankan kualitas semen cair babi Landrace.

\section{METODE PENELITIAN}

\section{Sumber semen}

Penelitian menggunakan semen segar yang berasal dari 3 ekor ternak babi Landrace jantan dengan kisaran umur 3-4 tahun. Semen yang digunakan memiliki kualitas spermatozoa yang baik dengan kriteria motilitas $\geq 75 \%$, Konsentrasi $\geq 200 \times 10^{6} \mathrm{sel} / \mathrm{ml}$ dan abnormalitas harus $\leq 20 \%$ (Jahnson et al., 2000).

\section{Penampungan Semen}

Penampungan semen babi landrace dilakukan dengan metode manual (glove hand methode) dan dilakukan pada pagi atau sore hari dengan interval penampungan 2 kali seminggu, sebelum penampungan ternak babi dimandikan untuk mencegah terjadinya kontaminasi.

\section{Evaluasi Semen Segar}

Semen yang telah ditampung segera dievaluasi baik secara makrokopis maupun mikrokopis, pengamatan makrokopis meliputi volume, bau, warna, konsistensi dan $\mathrm{pH}$, sedangkan secara mikrokopis pengamatan dilakukan di bawah mikroskop, untuk mengetahui gerakan masa, gerakan individu (motilitas), konsentrasi, hidup dan abnormalitas spermatozoa.

\section{Pencampuran Pengencer dan Semen}

Bahan pengencer dasar yang di gunakan dalam penelitian ini adalah yaitu tris yang sudah lama digunakan sebagai komponen dasar pengencer semen sapi, babi dan domba (Maxwell dan Salamon, 1993). Komposisi pengencer dasar tris dalam $100 \mathrm{ml}$ yang digunakan adalah sebagai berikut : Tris $2,98 \mathrm{~g}$, fruktosa $2 \mathrm{~g}$ dan asam sitrat $1,65 \mathrm{~g}$. Setelah pengencer tris sudah dilarutkan dalam $100 \mathrm{ml}$ akuabidestilata, kemudian ditambahkan $20 \mathrm{ml}$ kuning telur kedalam pegencer tersebut. Semen segar babi yang sudah dievaluasi kemudian diencerkan degen pengencer dasar lalu dibagi dalam tabung perlakuan dan diholding time selama 2 jam. Selanjutnya disentrifugasi dengan kecepatan 2000 rpm selama 15 menit. Setelah disentrifugasi, supernata dibuang dan pellet diencerkan kembali sesuai perlakuan:

$\mathrm{P}_{0}=$ tris kuning telur $(\mathrm{T}-\mathrm{KT})$

$\mathrm{P}_{1}=$ tris kuning telur $+\mathrm{VCO} 6 \%(\mathrm{~T}-\mathrm{KT}+\mathrm{VCO})$

$\mathrm{P}_{2}=$ tris kuning telur + minyak ikan $6 \%(\mathrm{~T}-\mathrm{KT}+\mathrm{MI})$

$\mathrm{P}_{3}=$ tris kuning telur + minyak zaitun $12 \%(\mathrm{~T}-\mathrm{KT}+$ $\mathrm{MZ}$ )

\section{Penyimpanan dan Evaluasi semen}

Setelah di encerkan sesuai perlakuan, semen cair disimpan pada sushu $18-20^{\circ} \mathrm{C}$ dan dievaluasi setiap 8 jam terhadap Motilitas, viabilitas, abnormalitas, membrane plasma untuh (MPU) dan $\mathrm{pH}$, Evaluasi di lakukan hingga motilitas semen cair dibawah $40 \%$.

\section{Analisis Data}

Rancangan yang digunakan adalah rancangan acak lengkap (RAL). Keseluruhan data yang terkumpul dianalisis dengan analysis of variance (Anova) dan dilanjutkan dengan uji Duncan dengan program software SPSS 22.0 for windows.

\section{HASIL DAN PEMBAHASAN}

\section{Karakteristik Semen Segar}

Semen segar ternak babi yang digunakanmemiliki kualitas spermatozoa yang baik dengan kriteria motilitas $\geq 75 \%$, Konsentrasi $\geq 200 \times 10^{6} \mathrm{sel} / \mathrm{ml}$ dan abnormalitas harus $\leq 20 \%$ (Jahnson et al.,2000). Kualitas semen segar yang dihasilkan dalam penelitian ini berada dalam kisaran normal dan layak untuk digunakan. 
Evaluasi secara mikroskopis menyatakan bahwa karakteristik semen segar babi landrace memilik warna putih-krem, konsistensi encer, volume $182.25 \pm 26.36 \mathrm{ml}$ dan $\mathrm{pH} 6.40 \pm 0.00$.

Tabel 1. Karakteristik semen segar babi landrace yang dievaluasi secara makroskopis

\begin{tabular}{lc}
\hline \multicolumn{2}{c}{ Makroskopis } \\
\hline Karakteristik Semen & Nilai Rataan \pm SD \\
\hline Volume $(\mathrm{ml})$ & $182.25 \pm 26.36$ \\
Warna & Putih susu \\
Konsistensi & Encer \\
pH & $6.40 \pm 0,00$ \\
\hline
\end{tabular}

Tabel 2. Karakteristik semen segar babi landrace yang dievaluasi secara mikroskopis

\begin{tabular}{|c|c|}
\hline \multicolumn{2}{|c|}{ Mikroskopis } \\
\hline Karakteristik Semen & Nilai Rataan \pm SD \\
\hline Konsentrasi $\left(\mathrm{x} 10^{6} \mathrm{sel} / \mathrm{ml}\right)$ & $256.69 \pm 19.27$ \\
\hline Motilitas (\%) & $77.50 \pm 2.88$ \\
\hline Viabilitas (\%) & $88.46 \pm 1.71$ \\
\hline Abnormalitas (\%) & $0.92 \pm 0.55$ \\
\hline
\end{tabular}

Karakteristik semen segar yang dihasilkan secara umum tidak berbeda dengan hasil penelitian Foeh dan Gaina (2017) yang menyatakan volume semen babi landrace tanpa gelatin berkisar $180-220 \mathrm{ml}$; selain itu hasil penelitian Robert (2006) juga menyatakan volume semen babi tanpa gelatin berkisar 150-250 ml. Karakteristik semen segar secara makroskopis dapat dipengaruhi oleh beberapa faktor seperti kualitas pakan yang diberikan, umur dari pejantan yang digunakan, frekuensi ejakulasi dan tingkat stimulasi selama proses penampungan.

Evaluasi secara mikroskopis memperlihatkan karakteristik semen segar babi landrace memiliki motilitas $77.50 \pm 2.88 \%$ dan viabilitas $88.46 \pm 1.71 \%$ yang tidak berbeda jauh dari hasil penelitian Foeh dan Gaina (2017) yang menyatakan motilitas dan viabilitas spermatozoa babi landrace $79.66 \%$ dan $80.04 \%$. Presentasi spermatozoa hidup lebih tinggi dibandingkan yang motil disebabkan karena spermatozoa yang hidup tidak semuanya motil progresif (Yusuf et al., 2017). konsentrasi spermatozoa babi landrace yang diperoleh $256,69 \times 10^{6} \mathrm{sel} / \mathrm{ml}$ hasil ini juga tidak berbeda jauh dari hasil penelitian Foeh dan Gaina (2017) yaitu 245-260 juta sel/ml. Beberapa faktor yang dapat memmengaruhi kualitas spermatozoa secara mikroskopis seperti genetik induk, jenis dan bangsa babi serta pakan yang diberikan. Selain itu jumlah ejakulat dapat memmengaruhi kualitas spermatozoa. Presentasi MPU spermatozoa dari hasil evaluasi tergolong sangat tingggi yaitu $91.62 \%$ dengan tingkat abnormalitas yang tergolong rendah yaitu $0.92 \%$.

\section{Motilitas Semen Cair Babi Landrace}

Motilitas spermatozoa sesudah pengenceran selalu digunakan sebagai acuan dalam penilaian semen untuk IB karena motilitas mempunyai peranan yang penting untuk keberhasilan fertilisasi (Hafez dan Hafez, 2000). Kecepatan gerakan spermatozoa untuk masingmasing spesies berbeda dan bervariasi sesuai dengan kondisi medium dan suhu lingkungan. Rataan persentase motilitas spermatozoa, babi landrace setelah penyimpanan dalam pengencer tris kuning telur dengan penambahan VCO, MI dan MZ dapat dilihat Tabel 3.

Hasil analisis menunjukkan bahwa sampai pada jam ke-8, seluruh perlakuan tidak berbeda secara nyata $(\mathrm{P}>0,05)$ terhadap persentase motilitas spermatozoa. Fakta ini mengindikasikan bahwa penambahan $\mathrm{VC} 0$, MI dan MZ dalam pengencer tris kuning telur tidak merubah kondisi pengencer yang memiliki fisiologis sama dengan spermatozoa babi landrace. Namun penyimpanan pada Suhu preservasi $18-20^{\circ} \mathrm{C}$ terjadi penurunan suhu dan mengakibatkan penurunan motilitas spermatozo pasca pengenceran (pp) ke pengamatan hingga 8 jam pertama sebesar 2-3\%. Hal ini di akibatkan oleh terjandinya cold shock pada spermatozoa akibat penurunan suhu. Penurunan motilitas juga disebabkan karena terjadinya peroksida lipit yang terjadi pada semen yang disimpan lama. Demikian juga dengan laju penurunan nilai motilitas spermatozoa, makin lama waktu penyimpanan makin rendah nilai motilitas spermatozoa yang diperoleh. Menurut Bebas et al. (2016) Hal ini kemungkinan disebabkan oleh semakin berkurangnya ketersediaan energi dalam pengencer akibat metabolisme spermatozoa.

Hasil uji lanjut jam ke-16 hingga jam ke56 menunjukkan bahwa atar perlakuan $\mathrm{T}$ $\mathrm{KT}+\mathrm{VCO}, \quad \mathrm{T}-\mathrm{KT}+\mathrm{MI}$ dan $\mathrm{T}-\mathrm{KT}+\mathrm{MZ}$ tidak berbeda nyata $(\mathrm{P}>0,05)$ terhadap persentase motil semen babi landrace, namun ke-3 perlakuan berpengaruh nyata dengan T-KT (kontrol). Hal ini diduga karena ketiga jenis minyak yang ditambahkan dalam pengencer tris mengandung vitamin $\mathrm{E}$ dan polifelon sebagai bahan antioksidan. Vitamin E yang dikandung mampu menghambat terjadinya proses peroksida lipid dengan cara memindahkan atom hidrogen kepada radikal peroksil. polifenol yang dikandung terdiri dari oleuropein, tyrosol, dan hydroxytyrosol. 
Tabel 3. Pengaruh virgin coconut oil (VCO), minyak ikan dan minyak zaitun dalam pengencer tris terhadap motilitas semen cair babi landrace.

\begin{tabular}{ccccc}
\hline Jam ke- & T-KT & T-KT+VCO & T-KT+MI & T-KT+MZ \\
\hline PP & $76.25 \pm 2.50^{\mathrm{a}}$ & $76.25 \pm 2.50^{\mathrm{a}}$ & $76.25 \pm 2.50^{\mathrm{a}}$ & $76.25 \pm 2.50^{\mathrm{a}}$ \\
8 & $73.75 \pm 4.78^{\mathrm{a}}$ & $74.25 \pm 0.95^{\mathrm{a}}$ & $74.25 \pm 0.50^{\mathrm{a}}$ & $75.00 \pm 0.81^{\mathrm{a}}$ \\
16 & $62.25 \pm 4.78^{\mathrm{a}}$ & $70.75 \pm 1.25^{\mathrm{b}}$ & $70.50 \pm 1.91^{\mathrm{b}}$ & $71.75 \pm 1.89^{\mathrm{b}}$ \\
24 & $57.50 \pm 6.45^{\mathrm{a}}$ & $66.25 \pm 4.57^{\mathrm{b}}$ & $65.50 \pm 4.43^{\mathrm{b}}$ & $67.50 \pm 3.69^{\mathrm{b}}$ \\
32 & $50.00 \pm 8.16^{\mathrm{a}}$ & $61.50 \pm 4.04^{\mathrm{b}}$ & $61.25 \pm 4.03^{\mathrm{b}}$ & $62.75 \pm 4.50^{\mathrm{b}}$ \\
40 & $41.25 \pm 8.53^{\mathrm{a}}$ & $55.25 \pm 5.85^{\mathrm{b}}$ & $54.50 \pm 5.68^{\mathrm{b}}$ & $56.25 \pm 5.85^{\mathrm{b}}$ \\
48 & $33.75 \pm 11.08^{\mathrm{a}}$ & $46.25 \pm 3.30^{\mathrm{b}}$ & $46.00 \pm 4.16^{\mathrm{b}}$ & $48.75 \pm 4.64^{\mathrm{b}}$ \\
56 & $26.25 \pm 13.76^{\mathrm{a}}$ & $40.75 \pm 1.25^{\mathrm{b}}$ & $40.25 \pm 0.50^{\mathrm{b}}$ & $44.00 \pm 1.41^{\mathrm{b}}$ \\
\hline
\end{tabular}

Superskrip yang berbeda pada baris yang sama menunjukkan perbedaan yang nyata $(\mathrm{P}<0,05)$

Oleuropein dan tyrosol dapat berperan sebagai antioksidan, sedangkan hydroxytyrosol berperan dalam melindungi membran sel. Menurut Hartono (2008) prinsip kerja dari antioksidan untuk menghambat otooksidasi pada lemak adalah dengan cara oksigen bebas di udara akan mengoksidasi ikatan rangkap pada asam lemak yang tidak jenuh, setelah itu radikal bebas yang terbentuk akan bereaksi dengan dengan oksigen dan menghasilkan peroksida aktif. Jika pada asam lemek yang di dalamnya tidak mengandung antioksidan, peroksida aktif akan bereaksi dengan ikatan rangkap lemak dan apabila ditambah suatu antioksidan, maka peroksida aktif akan bereaksi dengan antioksidan tersebut. Sehingga pembentukan radikal bebas dapat dihentikan dengan penambahan suatu antioksidan.

Presentasi spermatozoa motil tertinggi hingga jam ke-56 ialah $\mathrm{T}-\mathrm{KT}+\mathrm{MZ}$ meliki presentasi motilitas $(44.00 \pm 1.41 \%)$ dibandingkan dengan $\mathrm{T}-\mathrm{KT}+\mathrm{VCO} \quad(40.75 \pm 1.25 \%)$ dan $\mathrm{T}$ KT + MI $(40.25 \pm 0.50 \%)$. Sedangkan pada kontrol (T-KT) sudah dibawa $40 \%$ yaitu $(26.25 \pm 13.76 \%)$ hal ini sama dengan hasil penelitian Waluwanja et al., (2019) dengan penambahan minyak zaitun sebanyak $12 \%$ dalam pengencer sitrat kuning telur mampu mempertahankan motilitas semen cair babi duroc hingga jam 64 jam dengan persentasi motilitas $41,50 \pm 2.24 \%$ dibandingkan kontrol di jam ke-64 presentasi motilitas sebesar $8,00 \pm 2,74 \%$. demikian juga dengan hasil penelitian Harbin et al., (2016) menyatakan dengan penambahan sari buah mengkudu sebanyak 3\% sebagai bahan antioksidan kedalam pengencer sitrat kuning telur mampu mempertahankan motilitas semen cair babi Landrace hingga jam ke-32 dengan presentasi motilitas $40 \%$ dibandingkan dengan kontrol hanya mampu bertahan hingga jam ke-16 dengan presentasi motilitas $50,00 \pm 4,08 \%$.

\section{Viabilitas Semen Cair Babi Landrace}

Nilai viabilitas spermatozoa dalam pengencer T-KT dengan penambahan VCO, MI dan $\mathrm{MZ}$ mengalami penurunan seiring dengan lama waktu penyimpanan. Makin lama waktu penyimpanan makin rendah nilai viabilitas spermatozoa yang diperoleh, tingkat penurunan berbeda-beda antar kelompok perlakuan. Penurunan persentaseviabilitas spermatozoa semen babi selama proses penyimpanan pada suhu $18^{\circ} \mathrm{C}$ kemungkinan juga dapat disebabkan karena sumber nutrisi (glukosa) bagi spermatozoa mulai berkurang.

Tabel 4. Pengaruh virgin coconut oil (VCO), minyak ikan dan minyak zaitun dalam pengencer tris terhadap viabilitas semen cair babi Landrace

\begin{tabular}{ccccc}
\hline Jam ke- & T-KT & T-KT + VCO & T-KT+MI & T-KT+MZ \\
\hline PP & $86.50 \pm 2.22^{\mathrm{a}}$ & $91.11 \pm 3.18^{\mathrm{ab}}$ & $90.10 \pm 2.75^{\mathrm{ab}}$ & $92.80 \pm 3.74^{\mathrm{b}}$ \\
8 & $83.91 \pm 3.97^{\mathrm{a}}$ & $84.08 \pm 2.51^{\mathrm{a}}$ & $80.25 \pm 9.75^{\mathrm{a}}$ & $87.16 \pm 2.26^{\mathrm{a}}$ \\
16 & $76.68 \pm 4.93^{\mathrm{a}}$ & $82.57 \pm 2.74^{\mathrm{b}}$ & $81.99 \pm 3.25^{\mathrm{ab}}$ & $83.72 \pm 3.07^{\mathrm{b}}$ \\
24 & $66.66 \pm 5.13^{\mathrm{a}}$ & $76.95 \pm 3.13^{\mathrm{b}}$ & $76.05 \pm 2.30^{\mathrm{b}}$ & $79.18 \pm 1.87^{\mathrm{b}}$ \\
32 & $59.57 \pm 6.96^{\mathrm{a}}$ & $72.31 \pm 5.61^{\mathrm{b}}$ & $71.08 \pm 4.88^{\mathrm{b}}$ & $73.67 \pm 6.10^{\mathrm{b}}$ \\
40 & $51.30 \pm 9.19^{\mathrm{a}}$ & $66.94 \pm 4.25^{\mathrm{b}}$ & $66.26 \pm 4.59^{\mathrm{b}}$ & $69.00 \pm 5.51^{\mathrm{b}}$ \\
48 & $43.40 \pm 11.08^{\mathrm{a}}$ & $56.99 \pm 3.19^{\mathrm{b}}$ & $56.81 \pm 4.30^{\mathrm{b}}$ & $59.42 \pm 4.57^{\mathrm{b}}$ \\
56 & $36.33 \pm 12.84^{\mathrm{a}}$ & $51.51 \pm 1.11^{\mathrm{b}}$ & $50.82 \pm 0.42^{\mathrm{b}}$ & $54.78 \pm 1.50^{\mathrm{b}}$ \\
\hline
\end{tabular}

Superskrip yang berbeda pada baris yang sama menunjukkan perbedaan yang nyata $(\mathrm{P}<0,05)$ 
Hasil analisis statistik menggunakan analisis variance (ANOVA) terhadap persentase hidup spermatozoa menunjukkan bahwa pada pengamatan jam ke-16 hingga jam ke-56, untuk perlakuan T-KT+VCO, T-KT+MI dan T-KT+MZ tidak berbeda nyata $(\mathrm{P}>0,05)$ terhadap persentase hidup spermatozoa babi landrace namun ke-3 perlakuan berpengaruh nyata dengan T-KT (kontrol). Hal ini diduga karena kadar antioksidan yang ditambahkan dalam pengencer dapat mempengaruhi viabilitas spermatozoa, dengan penambahan antioksidan VCO, MI dan MZ dalam pengencer dapat melindungi spermatozoa dari kerusakan oksidatif, dan akhirnya berpengaruh pada kelangsungan hidup spermatozoa. Hal ini sesuai laporan Mittal et al. (2010) dimana kematian sel spermatozoa atau yang disebut apoptosis dapat terjadi apabila tidak ada perlindungan antioksidan. Menurut Hartono (2008) prinsip kerja dari antioksidan dalam menghambat oksidasi pada lemak antara lain: oksigen bebas diudara akan mengoksidasi ikatan rangkap pada asam lemak yang tidak jenuh, kemudian radikal bebas yang terbentuk akan beraksi dengan oksigen sehingga akan menghasilkan peroksida aktif.

Dari hasil analis di atas juga dapat laporkan bahwa rataan persentase spermatozoa hidup tertinggi hingga terenda pada jam ke-56 ialah pada perlakuan $\mathrm{T}-\mathrm{KT}+\mathrm{MZ}$ sebesar $54.78 \pm 1.50 \%$, T-KT+VCO $51.51 \pm 1.11 \%$, TKT+MI $50.82 \pm 0.42 \%$ dan T-KT $(36.33 \pm 12.84 \%)$. Hasil penelitian memperlihatkan bahwa kadar antioksidan dalam pengencer dapat memengaruhi viabilitas spermatozoa dibandingkan dengan kontrol (T-KT). Hal ini sama dengan hasil penelitian Waluwanja et al. (2019) dengan penambahan minyak zaitun sebanyak $12 \%$ dalam pengencer sitrat kuning presentasi spermatozoa hidup semen cair babi duroc hingga jam 64 jam sebesar $42,39 \pm 1.83 \%$ dibandingkan kontrol di jam ke-64 presentasi spermatozoa hidup sebesar $10.04 \pm 1.47 \%$. Hasil penelitian Harbin et al., (2016) yang melaporkan penambahan sari buah mengkudu sebanyak 3\% sebagai bahan antioksidan kedalam pengencer sitrat kuning telur terhadap kualitas semen cair babi landrace mampu menjaga presentasi spermatozoa hidup hingga jam ke-32 sebesar $49.45 \pm 5.08 \%$ dibandingkan dengan kontrol hanya mampu mempertahankan presentasi spermatozoa hidup hingga jam ke-28 sebesar $13.19 \pm 11.12 \%$.

\section{MPU Semen Cair Babi Landrace}

Penurunan kualitas sepermatozoa selama penyimpanan, baik presentasi motilitas maupun keutuhan membran plasma dipengaruhi oleh jumlah spermatozoa yang mati. Keberadaan zat yang bersifat toksik baik yang berasal dari spermatozoa mati maupun yang berasal dari bahan pengencer yang telah mengalami oksidasi akibat penyimpanan dapat menyebabkan tingginya kadar radikal bebas yang dapat merusak keutuhan membran plasma. Apabila membran plasma spermatozoa suda mengalami kerusakan, maka metabolisme spermatozoa akan tergangu dan mulai kehilangan motilitasnya sehingga mengakibatkan kematian spermatozoa (Yulnawati dan Setiadi, 2005).

Hasil analisis statistik menggunakan analisis variance (ANOVA) terhadap persentase MPU spermatozoa menunjukkan bahwa hingga pengamatan jam ke-16 seluruh perlakuan tidak berbeda secara nyata $(\mathrm{P}>0,05)$ terhadap persentase MPU spermatozoa. Fakta ini mengindikasikan bahwa penambahan $\mathrm{VC} 0$, MI dan $\mathrm{MZ}$ dalam pengencer tris kuning telur tidak merubah kondisi pengencer yang memiliki fisiologis sama dengan spermatozoa babi landrace.

Tabel 5. Pengaruh virgin coconut oil (VCO), minyak ikan dan minyak zaitun dalam pengencer tris terhadap MPU semen cair babi Landrace

\begin{tabular}{ccccc}
\hline Jam ke- & T-KT & T-KT+VCO & T-KT+MI & T-KT+MZ \\
\hline PP & $90.31 \pm 1.71^{\mathrm{a}}$ & $92.20 \pm 2.89^{\mathrm{a}}$ & $92.14 \pm 2.54^{\mathrm{a}}$ & $94.17 \pm 3.73^{\mathrm{a}}$ \\
8 & $88.37 \pm 3.42^{\mathrm{a}}$ & $86.16 \pm 2.71^{\mathrm{a}}$ & $86.78 \pm 2.25^{\mathrm{a}}$ & $89.13 \pm 1.92^{\mathrm{a}}$ \\
16 & $82.73 \pm 6.21^{\mathrm{a}}$ & $83.71 \pm 2.76^{\mathrm{a}}$ & $83.02 \pm 2.97^{\mathrm{a}}$ & $85.14 \pm 2.72^{\mathrm{a}}$ \\
24 & $68.32 \pm 4.48^{\mathrm{a}}$ & $78.87 \pm 2.12^{\mathrm{b}}$ & $77.91 \pm 2.45^{\mathrm{b}}$ & $80.63 \pm 2.48^{\mathrm{b}}$ \\
32 & $63.73 \pm 6.79^{\mathrm{a}}$ & $73.50 \pm 5.80^{\mathrm{ab}}$ & $69.83 \pm 5.68^{\mathrm{ab}}$ & $74.70 \pm 6.00^{\mathrm{b}}$ \\
40 & $55.98 \pm 8.79^{\mathrm{a}}$ & $68.67 \pm 4.96^{\mathrm{ab}}$ & $67.27 \pm 5.22^{\mathrm{ab}}$ & $69.69 \pm 5.90^{\mathrm{b}}$ \\
48 & $48.01 \pm 11.10^{\mathrm{a}}$ & $57.95 \pm 3.24^{\mathrm{b}}$ & $57.50 \pm 4.29^{\mathrm{b}}$ & $60.15 \pm 4.49^{\mathrm{b}}$ \\
56 & $41.01 \pm 12.89^{\mathrm{a}}$ & $49.96 \pm 6.43^{\mathrm{b}}$ & $51.93 \pm 0.50^{\mathrm{b}}$ & $55.66 \pm 1.64^{\mathrm{b}}$ \\
\hline
\end{tabular}

Superskrip yang berbeda pada baris yang sama menunjukkan perbedaan yang nyata $(\mathrm{P}<0,05)$ 
Pada pengematan jam ke-24 hingga jam ke-56 untuk perlakuan T-KT+VCO, T-KT+MI dan $\mathrm{T}-\mathrm{KT}+\mathrm{MZ}$ tidak berpengaruh nyata $(\mathrm{P}>0,05)$ terhadap persentase MPU spermatozoa babi landrace, namun ke-3 perlakuan berpengaruh nyata dengan T-KT (kontrol). Hal ini diduga akibat terdapatnya kandungan atioksidan pada VCO, MI dan MZ sehingga mampu menghambat terjadinya peroksida lipid pada membran spermatozoa. Rataan persentase spermatozoa hidup pada jam ke-56 pada perlakuan T-KT (41.01 $\pm 12.89 \%)$; T-KT+VCO $(49.96 \pm 6.43 \%)$; T$\mathrm{KT}+\mathrm{MI} \quad(51.93 \pm 0.50 \%) ; \quad$ dan $\quad \mathrm{T}-\mathrm{KT}+\mathrm{MZ}$ $(55.66 \pm 1.64 \%)$. Hasil tersebut dapat disimpulkan bahwa T-KT + MZ memiliki presentasi MPU tertinggi hingga jam ke-56. Hal ini menunjukan bahwa kadar antioksidan dalam pengencerT$\mathrm{KT}+\mathrm{MZ}$ dapat memengaruhi viabilitas spermatozoa, dengan penambahan antioksidan MZ dalam pengencer dapat melindungi spermatozoa dari kerusakan oksidatif, dan akhirnya berpengaruh pada kelangsungan hidup spermatozoa. Hal ini menujukan keefektifannya dalam menghambat terjadinya peroksida lipid pada membran plasma spermatozoa ternak babi lebih efektif dibandingkan kombinasi pengencer lainya (Waluwanja et al, 2019).

\section{KESIMPULAN}

Hasil penelitian ini dapat disimpulkan bahwa kombinasi pengencer dan antioksidan terbaik dalam pengencer tris untuk mempertahankan kualitas semen babi landrace hingga jam ke-56 adalah $\mathrm{P}_{3 \text { : }}$ tris kuning telur + minyak zaitun $12 \%(\mathrm{~T}-\mathrm{KT}+\mathrm{MZ})$ karena memiliki presentasi motilitas $(44,00 \pm 1,41 \%)$, viabilitas $(54,78 \pm 1,50 \%)$ dan MPU (55,66 $\pm 1,64 \%)$ yang tertinggi dibandingkan dengan kombinasi pengencer lainya.

\section{DAFTAR PUSTAKA}

Arifiantini, I., B. Purwantara dan W. W. Putra. 1999. Pengujian Keutuhan Membran Plasma Spermatozoa Semen Cair Domba Menggunakan Larutan Hipoosmotik. Prosiding Seminar Hasil-Hasil Penelitian Bidang Ilmu Hayat. Bogor: Pusat Antar Universitas Ilmu Hayat IPB.

Bebas, W., L. B. Geovany dan K. B. Made. 2016. Penambahan Vitamin E pada Pengencer BTS terhadap Daya Hidup dan Motilitas Spermatozoa Babi Landrace Pada
Penyimpanan $15 \mathrm{oC}$. Buletin Veteriner Udayana 8(1) : 1-7.

Foeh, N. D. F. K., dan C. D. Gaina. 2017. Sari Buah Lontar Sebagai Pengencer Alami Dalam Mempertahankan Kualitas Spermatozoa Babi. Jurnal Kajian Veteriner 5(1): 52-58.

Harbin, A., H. L. L. Belli, W. M. Nalley. 2016. Motilitas dan Viabilitas Spermatozoa Babi Landrace dalam Pengencer Sitrat Kuning Telur dengan Penambahan Level Sari Mengkudu yang Berbeda. Jurnal Nukleus Peternakan 5(2): 177-183.

Hartono, M., Suswardana, P. D. A. Saraswati, and S. Radiono. 2008. Virgin Coconut Oil Protection Against UV Blnduced Erithema and Pigmentation. BIKKK (Berkala Ilmu Kesehatan Kulit dan Kelamin). Desember 2008. 3. 20. 208-211.

Jhonson, L. A., K. F. Weitze, P. Fiser, and W. M. C. Maxwell. 2000. Storage of boar semen. J Anim Sci. 62 : 143-172.

Jones, R. C., and I. C. A. Martin. 1973. The effects of dilution, egg yolk and cooling to $5 \mathrm{oC}$ on the ultrastructure of ram spermatozoa. J Reprod Fertil. 32: 311-320

Lenzi, A., L. Gandini, F. Lombardo, M. Picardo, V. Maresca, E. Panfili, F. Tramer, C. Boitani, and F. Dondero. 2002. Polyunsaturated fatty acids of germ cell membranes, glutathione and glutathionedependent enzyme-PHGPx: from basic to clinic. Contraception 65: 301-304.

Mittal., Manish, Mohamad, S. Riswan, T. Khiem, P. R. Sekhar, and B. M. Asrar. 2014. Reactive Oxygen Spesies In Inflammation and Tissue Injury. Antioxiants \& Redox Signaling 20(7) : 1126-1167.

Robert, V. K. 2006. Semen Processing, Extending \& Storage for Artifi Cial Insemination in Swine. Dep.Of Animal Science University of Illinois.

Waluwanja, Y. U. D., W. M. Nalley, T. M. Hine, dan K. Uly. 2019. Efek Berbagai Konsentrasi Minyak Zaitun Ekstra Virgin (Oleum olivae) dalam Pengencer Sitrat Kuning Telu terhadap Kualitas Semen Cair Babi Duroc. Jurnal Nukleus Peternakan. 6 (2): 55-62. 
Yulnawati and M. A. Setiadi. 2005. Motilitas Dan Keutuhan Membran Plasma Spermatoza Epididimis Kucing Selama Penyimpanan Pada Suhu $4^{\circ} \mathrm{C}$. Media Kedokteran Hewan 21(3): 100-104.
Yusuf, T. L., R. I. Arifiantini, R. R. Dapawole, dan W. M. Nalley. 2017. Kualitas Semen Beku dalam Pengencer Komersial yang Disuplrmrntasi Dengen Trehalosa. Jurnal Veterriner 18 (1) : 69-75. 